\title{
Effect of unripe banana and pigeon pea flour on the chemical, anti-nutritional and sensory properties of whole wheat- based cookies
}

\author{
Adejumo $\mathrm{PO}^{1,}{ }^{*}$, Adejumo $\mathrm{AO}^{2}$, Edebiri $\mathrm{OE}^{1}$ and Olukoya $\mathrm{FO}^{1}$ \\ ${ }^{1}$ Department of Food Technology, Auchi Polytechnic, Auchi, Edo State, Nigeria. \\ ${ }^{2}$ Department of Food Science and Technology, Federal University of Technology, Akure, Ondo State, Nigeria.
}

Publication history: Received on 11 June 2020; revised on 11 July 2020; accepted on 14 July 2020

Article DOI: https://doi.org/10.30574/gscarr.2020.4.1.0050

\begin{abstract}
The chemical, anti-nutritional and sensory properties of cookies made with whole wheat (Triticum aestivum), unripe banana (Musa sapientum) and Pigeon pea (Cajanus cajan) flours were evaluated. The flours were prepared by drying, cracking, winnowing, milling and sieving of each of the materials. The flours were mixed in different proportions and were baked as cookies. The chemical analysis revealed that the cookies at varied composition (sample WBPA, WBPB, WBPC and WBPD) had moisture, ash, fat, crude fiber, crude protein and carbohydrate contents ranged from $2.85 \%$ 7.34\%; 2.27\% - 2.75\%; 16.50\% - 20.29\%; 3.37\% - 5.03\%; 9.13\% - 12.33\%; 57.03\% - 62.80\% respectively. Significant difference occurred among the samples. Increase in substitution of whole wheat with unripe banana and pigeon pea increase the ash, crude fiber protein and decrease the carbohydrate content. The result for anti-nutritional properties of the cookies for tannin, oxalate, phytate and cyanide were $(0.11-0.16) \mathrm{mg} / 100 \mathrm{~g},(0.04-0.39) \mathrm{mg} / 100 \mathrm{~g}$, (0.04 - 0.08) $\mathrm{mg} / 100 \mathrm{~g}$ and $(0.0 .02-0.03) \mathrm{mg} / 100 \mathrm{~g}$ respectively. The anti-nutritional content were not different significantly especially oxalate and cyanide content as the inclusion increases. The sensory evaluation was also carried out for color, aroma, taste, crispiness and general acceptability; the results were $6.50-7.80,7.70-8.30,7.40-7.80,7.40-7.80$ and 7.50- 8.50. Sample WBPC had the highest acceptability when compared with samples WBPB and sample WBPD. The results of the study showed that as substitution of whole wheat with unripe banana and pigeon pea increases the nutritional value in terms of proximate composition of the cookies increases, while cyanide content reduce. Sample WBPC (80:5:5) with the highest protein, ash, fibre, low carbohydrate content, highest acceptability and low anti nutritional content established that it is possible to use whole wheat, unripe banana and pigeon pea flour blends to produce acceptable cookies with increase nutritional value; hence it was recommended.
\end{abstract}

Keywords: Cookies; Whole-wheat; Pigeon pea; Banana; Flour

\section{Introduction}

Cookies are a form of confectionery product dried to low moisture content, widely consumed by individuals among all age groups [1]. It represents the largest category of snack foods in most parts of the world [2]. Cookies are nutritive snacks produced from palatable dough which transformed into appetizing product through heat application in an oven [3]. They are popular illustration of ready-to-eat bakery product which possesses several attractive features such as wide consumption, convenient with long shelf life and with ability to serve as vehicle for important nutrient [4]. Cookies are convenient food products popularly consumed by nearly all levels of society due to varied taste, easy availability, longer shelf life and low cost among other processed foods. Cookies have become loved fast food because they are easy to carry out, tasty to eat, contain digestive and dietary fiber of vital importance and reasonably cheap [5].

Cookies are concentrated food and substantial source of energy due to their high carbohydrates contents, fats and low moisture. Nutritionally, their quality can be enriched or fortified by including a number of other ingredients in the

\footnotetext{
${ }^{*}$ Corresponding author: Adejumo PO
} 
recipe; hence cookies have a great potential of becoming a good medium for providing special dietary needs. Euromonitor International [6] reported that the projected global market for cookies in 2016 is around $\$ 1,825.00$ billion dollars. In Nigeria like many other developing countries, the increasing phenomenon of urbanization coupled with the growing number of working mothers, have contributed greatly to the popularity and increased consumption of snack foods such as cookies and biscuits. Cookies can be made from hard dough, hard sweet dough or soft dough which is characterised by a formula high in sugar, shortening and low in water content. The main ingredients of cookies are wheat flour, fat (margarine), sugar, water other ingredients such as milk, salt, aerating agent, emulsifier, flavour and colour are also added. Wheat flour which is the flour of choice for producing cookies and other baked food products, is uneconomical in many countries of the world due to importation. To produce baked goods, countries like Nigeria rely on importation of wheat leading to high purchase price for the finished product. The production of wheat-based baked products like cookies at an affordable cost therefore requires the development of an adequate substitute for wheat. The substitute should be one that is readily available, cheap and able to replace wheat flour in terms of functionality [7].

Composite flours produced from cereals and legumes have the advantage of improving the overall nutrition. The selection of the composite flour blends involve the materials being readily available, culturally acceptable and provide increased nutritional potentials [8]. Wheat (Triticum aestivum) is the most extensively grown crop in the world with about 237 million hectares cultivated annually which account for a total of 420 million ton. It is the source of at least one-fifth of man's calorie intake and mainly grown for its highly nutritious and useful grain as one of the top three most produced crops along with rice and corn.

Banana (Musa sapientum) is fourth most important food crop after rice, wheat and maize and grown worldwide in tropical countries. It has short shelf-life after harvest due to its climacteric nature. Postharvest losses are usually encountered due to poor handling, bulk transportation, rapid ripening and poor processing technologies [9]. Processing of fresh unripe banana fruits is a means to reduce losses and add value to the flour [10] which could be used to produce products like cookies, high fibre bread $[11,12]$. The flour is a good source of carbohydrate with high level of resistant starch that may help control blood sugar, manage weight and lower blood cholesterol [10].

Pigeon pea (Cajanus cajan) and unripe banana are staples in Nigeria hence their utilization in the production of cookies will reduce importation of wheat, save foreign exchange, improve the nutritional value of the cookies, enhance food security and, increase the economic power of local farmers in developing countries. The aim of this research is to determine the chemical anti-nutritional and sensory properties of cookies produced from composite flours of whole wheat, pigeon pea and unripe banana.

\section{Material and methods}

\subsection{Materials Procurement}

Whole wheat, Pigeon pea and mature unripe banana, and ingredients such as margarine, sugar, salt, egg, milk powder, sodium bicarbonate and flavor (butter scotch) were purchased from Uchi Market in Auchi, Edo State, Nigeria.

\subsection{Methodology}

Preparation of Whole wheat, Pigeon pea and Unripe Banana Flour

Whole Wheat grain was manually winnowed, sorted to removed defected grains and foreign materials like stones and stalk, milled with plate mill and sieved through a mesh of 40-mesh sieve. The flour was packaged in airtight plastic container, labeled and stored at ambient temperature $\left(27 \pm 2{ }^{\circ} \mathrm{C}\right)$ for subsequent use. Pigeon pea flour and unripe banana flour were prepared according to the methods of Ohizua et al. [13] with slight modification. Unripe banana fruit were peeled and treated with $0.05 \%\left(\mathrm{w} / \mathrm{v}\right.$ ) sodium metabisulphite sliced to an average size of $2 \mathrm{~mm}$, dried at $60{ }^{\circ} \mathrm{C}$ in air oven and milled using plate mill then sieved with 40-mesh sieve. Pigeon pea seeds were subjected to drying at $60{ }^{\circ} \mathrm{C}$ for 3hours, cracked, winnowed to remove the seed coat, milled using plate mill and sieve to pass through 40-mesh. The obtained sieved fine flour from the three samples was packed separately in air-tight container for composite flour cookies formulation.

\subsection{Composite Flour Formulation}

Four samples of composite flour were formulated with different proportion of Whole Wheat, Unripe banana and Pigeon pea and designated as WBPA, WBPB, WBPC and WBPD as shown on Table 1. 
Table 1 Composite flour blends formulation.

\begin{tabular}{lllll}
\hline Samples & WBPA & WBPB & WBPC & WBPD \\
\hline Whole Wheat flour & 100 & 95 & 90 & 80 \\
Unripe banana & 0 & 2.5 & 5 & 10 \\
Pigeon Pea & 0 & 2.5 & 5 & 10 \\
\hline
\end{tabular}

\subsection{Cookies Production}

The cookies basic formulation was $100 \mathrm{~g}$ flour, $40 \mathrm{~g}$ fat, $25 \mathrm{~g}$ sugar, $1 \mathrm{~g}$ sodium bicarbonate, $5 \mathrm{ml}$ liquid flavor (butter scotch), $1 \mathrm{~g}$ salt and 1whole egg. The dry ingredients were manually mixed together before adding the wet ingredients to form consistency dough required for cookies using the rub-in method. The dough was kneaded, flattened to a uniform thickness on a rolling board and cut into different shapes. The oven was pre-heated and the cut dough was baked in the oven at $180{ }^{\circ} \mathrm{C}$ for 15 minutes. The procedure was carried out for the four samples respectively. The cookies were cooled, packaged in high-density polyethylene bags, labeled and stored at ambient temperature $27 \pm 2{ }^{\circ} \mathrm{C}$ and kept for analyses.

\subsection{Determination of Chemical Properties of Cookies}

The Moisture ash, fat, crude fibre and protein contents were determined using the method of AOAC [14], while the carbohydrate was determined by difference by subtracting the total sum of the percentage of moisture ash, fat, crude fibre and protein contents from hundred (100).

\subsection{Determination of Anti-Nutritional Properties of the Cookies}

The tannin content of the flour mixes was determined as described by Makkar et al. [15] using Folin Denis Reagents. Phytate content was determined using spectrophotometric method as described by Pearson [16] while the oxalate content of the samples was determined using the method described by Ukpabi and Ejidoh [17]. Hydrogen cyanide was determined using the alkaline picrate spectrophotometric method as described by Balagopalan et al. [18].

\subsection{Determination of Sensory Properties of Cookies}

Twenty-four hours after preparation of the cookies, sensory evaluation was carried out. A total of 20 semi trained panelists who were familiar with the quality attributes of the cookies were used among the staff and students of the Department of Food Technology, Auchi Polytechnic, Auchi. Selection was based on panelist being a regular consumer of cookies and not allergic to any cookies. Panelists were instructed to evaluate appearance, aroma, taste, crispness, and general acceptability of the cookies. A nine-point Hedonic scale was used according to Ihekoronye and Ngoddy [19]. Samples were coded with alphabets and presented to panelists who were instructed to rinse their mouths with water after every sample.

\subsection{Statistical Analysis}

Data obtained were subjected to a one-way Analysis of Variance (ANOVA) using the software Statistical Package for Social Sciences (SPSS) version 17 (SPSS, Inc, Chicago, USA) to determine significant difference at P<0.05. Means were separated using Duncan's Multiple Range Test (DMRT).

\section{Results and discussion}

The result for the proximate composition of cookies produced from the formulated flour blend is shown on Table 2. The value for moisture ranges from $2.85 \%$ to $7.34 \%$ for the four samples with sample WBPD having the lowest value and sample WBPC having the highest value. Significant difference occurred among the samples. The moisture contents of the cookies were generally low; this would prolong the shelf life of the cookies. Moisture content and water activity have been reported to have great effects on the keeping quality and shelf life of foods [20]. The ash content ranged from $2.28 \%$ to $2.75 \%$, significant difference did not occur between samples WBPA and WBPB also there was no significant difference between samples WBPC and WBPD. The ash content is an indication of the quantity of minerals in the product; it represents the inorganic elements obtained in a food material after the combustion of the organic materials. The inorganic materials consist of mineral element such as calcium, magnesium, iron, phosphorus, potassium etc which are important for building rigid structures and regulatory functioning of the body [21]. The values for fat, fibre and protein ranges from $16.50 \%-20.29 \%, 3.77 \%-5.03 \%$ and $9.13 \%-12.33 \%$ respectively. Significant difference occurred 
among the samples. The values recorded were within the standard limit (15\% - 20\%) for soft dough biscuits. The fibre content increase with the increase in the inclusion of banana and pigeon pea flour with the highest value recorded by sample WBPD and lowest value for sample WBPA which was 100 percent whole wheat flour. Daramola and Osanyinlusi [22] reported that unripe banana and pigeon pea flour are good source of fiber; this could justify the results obtained in this study. Crude fiber composition is a measure of the quality of indigestible cellulose, pentose, lignin and other components present in food with little food value but provide bulk necessary for peristaltic action in the intestinal tract; Crude fibre helps in the prevention of heart diseases, colon cancer and diabetes [23, 24].

The protein content increased with the increase in pigeon pea flour, similar trend was observed by other authors [25, 26]. Protein is required for growth, repair and maintenance of the body. It also acts as enzymes and hormones, maintain fluid, electrolyte and acid-base balance also strong immune system. Protein also act as carriers for other nutrients such as lipids, iron, vitamin A, sodium and potassium [27]. The result indicates that cookies of improved protein content could be produced from blends of whole wheat, unripe banana and pigeon pea flours. The carbohydrate content of the cookies ranges from $57.03 \%$ to $62.80 \%$. The carbohydrate content of the cookies decreases as the percentage of pigeon pea and unripe banana flour increase this may be due to the low amount of carbohydrate content in pigeon pea and high sugar content in unripe banana [28]. The result of the proximate composition revealed that inclusion of 5\% each of unripe banana and pigeon pea into whole wheat (sample WBPC) for cookies production had the best nutritional value.

Table 2 Proximate result for cookies produce from Whole wheat, Banana and Pigeon pea composite flour.

\begin{tabular}{lllllll}
\hline Sample & \%Moisture & \%Ash & \%Fat & \%Fibre & \%Protein & \%Carbohydrate \\
\hline WBPA & $5.26 \pm 0.03^{\mathrm{C}}$ & $2.28 \pm 0.01^{\mathrm{a}}$ & $18.59 \pm 0.08^{\mathrm{C}}$ & $3.77 \pm 0.08^{\mathrm{a}}$ & $9.13 \pm 0.07^{\mathrm{a}}$ & $60.97 \pm 0.03^{\mathrm{b}}$ \\
WBPB & $4.23 \pm 0.00^{\mathrm{b}}$ & $2.27 \pm 0.02^{\mathrm{a}}$ & $16.50 \pm 0.00^{\mathrm{a}}$ & $3.93 \pm 0.01^{\mathrm{b}}$ & $10.28 \pm 0.011^{\mathrm{b}}$ & $62.80 \pm 0.12 \mathrm{C}$ \\
WBPC & $7.34 \pm 0.03^{\mathrm{d}}$ & $2.75 \pm 0.07^{\mathrm{b}}$ & $17.07 \pm 0.07^{\mathrm{b}}$ & $4.25 \pm 0.04^{\mathrm{C}}$ & $11.33 \pm 0.17^{\mathrm{C}}$ & $57.25 \pm 0.23^{\mathrm{a}}$ \\
WBPD & $2.85 \pm 0.05^{\mathrm{a}}$ & $2.47 \pm 0.03^{\mathrm{b}}$ & $20.29 \pm 0.03^{\mathrm{d}}$ & $5.03 \pm 0.02^{\mathrm{d}}$ & $12.33 \pm 0.10^{\mathrm{d}}$ & $57.03 \pm 0.11^{\mathrm{a}}$ \\
\hline
\end{tabular}

Values are means \pm SD (standard deviation) of triplicate determinations. Means on the same column with different superscripts are significantly different at $\mathrm{P}<0.05$. WBPA $=100 \%$ whole wheat $+0 \%$ unripe banana $+0 \%$ pigeon pea $\mathrm{WBPB}=95 \%$ whole wheat $+2.5 \%$ unripe banana $+2.5 \%$ pigeon pea $\mathrm{WBPC}=90 \%$ whole wheat $+5 \%$ unripe banana $+5 \%$ pigeon pea $\mathrm{WBPD}=80 \%$ whole wheat $+10 \%$ unripe banana $+10 \%$ pigeon pea.

The nutritional values of food are usually reduced by anti-nutrients resulting to reduction in bioavailability, digestibility and utilization of nutrients. The result on Table 3 showed that tannin content ranged from $0.11 \mathrm{mg} / 100 \mathrm{~g}$ to 0.16 $\mathrm{mg} / 100 \mathrm{~g}, 0.38 \mathrm{mg} / 100 \mathrm{~g}-0.40 \mathrm{mg} / 100 \mathrm{~g}$ for oxalate, $0.04 \mathrm{mg} / 100 \mathrm{~g}-0.08 \mathrm{mg} / 100 \mathrm{~g}$ for phytate and $0.02 \mathrm{mg} / 100 \mathrm{~g}$ to $0.03 \mathrm{mg} / 100 \mathrm{~g}$ for cyanide. Significant difference occurred among the samples for tannin, oxalate, phytate and cyanide content. The low tannin content is good because they form insoluble complexes with proteins to decrease digestibility of proteins. They can also provoke astringent reaction in the mouth and decrease palatability of food and cause damage to intestinal tract and enhance carcinogenesis [29,30]. Inyang and Ekpo [31] reported that tannin is present in all parts of the plants which inhibit trypsin, chymotrypsin, amylase and lipase activities. The low oxalate values obtained is advantageous to man as lethal dose reported for man should be between 2 to $5 \mathrm{~g} / \mathrm{kg}$ hence the cookies are safe from the stand point of oxalate level [32]. Oxalate is known to form complexes with most essential trace elements such as calcium resulting to unavailability for enzymatic and other metabolic activities [30]. Phytate content of the cookies samples increases as the percentage of unripe banana and pigeon pea flour increase although the values recorded were low $(0.04$ to $0.09 \mathrm{mg} / 100 \mathrm{~g}$ ). Phytate at low and high $\mathrm{pH}$ form complexes with protein causing indigestion of food and flatulence. Okpala and Okoli [33] reported low values for cookies ( 0.56 to $0.70 \mathrm{mg} / 100 \mathrm{~g}$ ) produced from pigeon pea, cocoyam and sorghum flour blends. The values recorded in this study are below the recommended limit for phytate that is 250 to 500 $\mathrm{mg} / 100 \mathrm{~g}$ [34]. The value for cyanide was low with the increase in substitution of unripe banana and pigeon pea flour. The result in this study showed that unripe banana and pigeon pea flour are not rich in cyanide.

Table 3 Anti nutritional properties of cookies (mg/100g).

\begin{tabular}{lllll}
\hline Sample & Tannin & Oxalate & Phytate & Cyanide \\
\hline WBPA & $0.13 \pm 0.01^{\mathrm{a}}$ & $0.38 \pm 0.01^{\mathrm{b}}$ & $0.04 \pm 0.01^{\mathrm{a}}$ & $0.02 \pm 0.00^{\mathrm{c}}$ \\
WBPB & $0.16 \pm 0.01^{\mathrm{ab}}$ & $0.39 \pm 0.00^{\mathrm{a}}$ & $0.05 \pm 0.01^{\mathrm{a}}$ & $0.02 \pm 0.00^{\mathrm{a}}$ \\
WBPC & $0.15 \pm 0.00^{\mathrm{b}}$ & $0.40 \pm 0.01^{\mathrm{b}}$ & $0.08 \pm 0.01^{\mathrm{b}}$ & $0.02 \pm 0.00^{\mathrm{b}}$ \\
WBPD & $0.11 \pm 0.01^{\mathrm{a}}$ & $0.37 \pm 0.00^{\mathrm{a}}$ & $0.09 \pm 0.01^{\mathrm{b}}$ & $0.03 \pm 0.00^{\mathrm{d}}$ \\
\hline
\end{tabular}


Values are means \pm SD (standard deviation) of triplicate determinations. Means on the same column with different superscripts are significantly different at $\mathrm{P}<0.05$. WBPA $=100 \%$ whole wheat $+0 \%$ unripe banana $+0 \%$ pigeon pea $\mathrm{WBPB}=95 \%$ whole wheat $+2.5 \%$ unripe banana $+2.5 \%$ pigeon pea $\mathrm{WBPC}=90 \%$ whole wheat $+5 \%$ unripe banana $+5 \%$ pigeon pea $\mathrm{WBPD}=80 \%$ whole wheat $+10 \%$ unripe banana $+10 \%$ pigeon pea.

Table 4 showed the mean sensory result scored by panelist for appearance, aroma, crispiness, taste and general acceptability for cookies produced from composite of whole wheat, Unripe banana and pigeon pea flours. Appearance and taste are important sensory attributes that affect the acceptability of food products. There was no significant $(\mathrm{P}>0.05)$ different in the mean values for appearance of samples WBPA and WBPC but significant difference occurred between samples WBPB and WBPD. The taste, aroma and crispness for cookies produced from the composite flour were not significantly different. The mean scores for crispiness of the cookies insignificantly $(\mathrm{P}>0.05)$ decreased with increased in pigeon pea and unripe banana flour inclusion. The mean scores for overall acceptability of the cookies showed that cookies produced from blends of $90 \%$ whole wheat, $5 \%$ unripe banana and 5\% pigeon pea flours (WBPC) as well as $100 \%$ whole wheat, $0 \%$ unripe banana and $0 \%$ pigeon pea flours (WBPA) were the most preferred cookies and were significantly $(\mathrm{P}<0.05)$ different from the rest of the cookies. The result of sensory quality revealed that substitution of whole wheat flour with $5 \%$ each of pigeon pea and unripe banana flour is best.

Table 4 Sensory result of cookies from the composite flour.

\begin{tabular}{llllll}
\hline Sample & Appearance & Aroma & Crispiness & Taste & General Acceptability \\
\hline WBPA & $7.70 \pm 0.37^{\mathrm{ab}}$ & $8.30 \pm 0.26^{\mathrm{a}}$ & $7.70 \pm 0.34^{\mathrm{a}}$ & $7.60 \pm 0.40^{\mathrm{a}}$ & $8.50 \pm 0.22^{\mathrm{b}}$ \\
WBPB & $7.80 \pm 0.39^{\mathrm{b}}$ & $7.80 \pm 0.44^{\mathrm{a}}$ & $8.20 \pm 0.33^{\mathrm{a}}$ & $7.80 \pm 0.25^{\mathrm{a}}$ & $7.90 \pm 0.28^{\mathrm{ab}}$ \\
WBPC & $7.70 \pm 0.21^{\mathrm{ab}}$ & $7.70 \pm 0.030^{\mathrm{a}}$ & $7.50 \pm 0.27^{\mathrm{a}}$ & $7.40 \pm 0.45^{\mathrm{a}}$ & $8.40 \pm 0.22^{\mathrm{ab}}$ \\
WBPD & $6.50 \pm 0.58^{\mathrm{a}}$ & $7.70 \pm 0.40^{\mathrm{a}}$ & $7.40 \pm 0.50^{\mathrm{a}}$ & $7.40 \pm 0.69^{\mathrm{a}}$ & $7.50 \pm 0.45^{\mathrm{a}}$ \\
\hline
\end{tabular}

Values are means \pm SD (standard deviation) of triplicate determinations. Means on the same column with different superscripts are significantly different at $\mathrm{P}<0.05$. WBPA $=100 \%$ whole wheat $+0 \%$ unripe banana $+0 \%$ pigeon pea $\mathrm{WBPB}=95 \%$ whole wheat $+2.5 \%$ unripe banana $+2.5 \%$ pigeon pea $\mathrm{WBPC}=90 \%$ whole wheat $+5 \%$ unripe banana $+5 \%$ pigeon pea $\mathrm{WBPD}=80 \%$ whole wheat $+10 \%$ unripe banana $+10 \%$ pigeon pea.

\section{Conclusion}

The results from this study showed that sample WBPC with highest protein, ash, fibre, low carbohydrate content, highest acceptability and low anti nutritional content have demonstrated that it is possible to use whole wheat, unripe banana and pigeon pea flour blends to produce acceptable cookies with increase nutritional value. The use of these locally grown crops to produce cookies will go a long way in reducing dependence on importation of wheat flour thereby reduce foreign exchange use, it will also increase the production of these locally grown crops, consumption, utilization, economic power of local farmers and increase protein intake of the consumers of the product. It is recommended therefore that the flour blends at 80:5:5 should be used in baking industries to create awareness and increase the availability of cheap healthy products.

\section{Compliance with ethical standards}

\section{Acknowledgments}

We acknowledged the Management of Auchi Polytechnic, Auchi, Edo State, Nigeria. It is also worth mentioning the Department of Food Technology for the opportunity given to use her state of the art laboratory equipment during the course of the research.

\section{Disclosure of conflict of interest}

Authors agree that there is no conflict of interest.

\section{References}

[1] Okaka JC. (2009). Handling, storage and processing of plant foods. Academy publishers Enugu, Nigeria, 132.

[2] Lorenz K. (1983). Protein fortification of Biscuits. Cereal Foods World, 28, 449-452.

[3] Olaoye OA, Onilude AA and Idowu OA. (2007). Quality characteristics of bread produced from composite flour of wheat, plantain and soybean. African Journal of Biotechnology, 5, 1102-1106. 
[4] Ajibola LC, Kleen DF and Reyer KO. (2015). Nutritional Evaluation of cookies produced from pigeon pea, cocoyam and sorghum flour blends. African Journal of Biotechnology, 10(3), 433-438.

[5] Farheena PO, Golu S and Theenar KI. (2015). Functional and postharvest utilization of commercial and noncommercial fruit cultivars. Comprehensive Reviews in Food Science and Food Safety, 12(5), 509-522.

[6] Euromonitor International. (2012). Global Biscuits (cookies) Market: Indulgence and quality still thriving.

[7] Eneche EH. (1999). Biscuit making potentials of millet/pigeon pea flour blends. Plant Food Human Nutrition, 54, 21-27.

[8] Akobundu ENT, Ubbaonu CN and Ndupuh CE. (1998). Studies on the baking potential of non-wheat composite flours. Journal of Food Science and Technology, 25, 211-214.

[9] Akcoaz H. (2011). Analysis of energy use for banana production: A case study from Turkey. African Journal of Agricultural Resources, 6(25), 5618-5624.

[10] Pragati S, Genitha I and Ravish R. (2014). Comparative study of ripe and unripe banana flour during storage. Journal of Food Processing Technology, 5, 3-8.

[11] Juarez-Garcia E, Agama-Acevedo ESG, Sayago-Ayerdi SL, Rodriguez-Ambriz and Bello-Perez LA. (2006). Composition, digestibility and application in bread making of banana flour. Plant Foods Human Nutrition, 61, 131-137.

[12] Aparicio-Saguilan A, Sayago-Ayerdi SG, Vargas-Torres ATJ, Ascencio-Otero TE and Bello-Perez LA. (2014). Slowly digestible cookies prepared from resistant starch-rich lintnerized banana starch. J. Food Comp. Anal, 20, 175181.

[13] Ohizua EA, Adeola AA, Idowu MA, Sobukola OP, Afolabi TA, Ishola R and Oykale TO. (2017). Nutrient Composition, functional and pasting properties of unripe cooking banana, pigeon pea and sweet potato flour blends. Food Sciences and Nutrition, 5(3), 750-762.

[14] AOAC (2005). Official methods of analysis (18th ed.), Association of Official Analytical Chemists, Washington, DC, U.S.A.

[15] Makkar HPS, Blummed MB and Becken NK. (1993). Determination of tannins and their correlation with chemical and protein precipitation method. Journal of Food Science and Agriculture, 61, 161-185.

[16] Pearson D. (1976). The Chemical analysis of foods. (7th ed.). Churchill, Livingstone.

[17] Ukpabi UI and Ejidoh JI. (1989). Effect of deep oil frying on the oxalate content and degree of itching of cocoyam (Xanthosoma and Colocasia Spp.) Technical paper presentation at the 5th Annual Conference of the Agricultural Society of Nigeria. Federal University of Tech. Owerri, Nigeria.

[18] Balagopalan C, Padmaja G, Nanda S and Moorthy SN. (1988). Cassava in food, feed and industry. CRC Press, Inc, Boca Raton, Florida.

[19] Ihekoronye AI and Ngoddy PO. (1985). Integrated Food Science and Technology for the Tropics. MacMillan Edu. Publishers, London, 172-193.

[20] Eke-Ejiofor J and Owuno F. (2012). Functional and pasting properties of wheat/three-leaved yam (Dioscorea dumentorum) composite flour blend. Global Research Journal of Agricultural and Biological Sciences, 3, 330-335.

[21] Akajiaku LO, Kabuo NO, Alagbaoso SO, Orji IG and Nwogu AS. (2018). Proximate, Mineral and Sensory Properties of Cookies Made from Tiger-Nut Flour. Journal of Nutrition and Dietetic Practice, 2, 001-005.

[22] Daramola B and Osanyinlusi SA (2006). Production, characterization and application of banana (Musa spp) flour in whole maize. African Journal of Biotechnology, 5(10), 992-995.

[23] Anderson JW, Baird P, Davis RH Jr, Ferreri S and Knudtson M. (2009). Health benefits of dietary fibre. Journal of Nutritional Review, 67, 188-205.

[24] Slavin J, Jacobs DR and Marquart L. (1997). Whole-grain consumption and chronic disease: Protective mechanisms. Journal of Nutrition and Cancer, 27, 14-21.

[25] Anuonye JC, Jigam AA and Ndaceko GM. (2012). Effects of extrusion-cooking on the nutrient and anti-nutrient composition of pigeon pea and unripe plantain blends. Journal of Applied Pharmaceutical Science, 2, 158-162.

[26] Silky MPG and Tiwari A. (2014). Development of high protein biscuit using pigeon pea broken flour. International Journal of Engineering and Innovative Technology, 4, 84-94. 
[27] Mahan K and Escott-Stump S (2008). Krause's food and nutrition therapy, 12th edition Canada; Saunders Elsevier.

[28] Ayo-Omigie HN and Ogunsakin R. (2013). Assessment of chemical, rheological and sensory properties of fermented maize-cardaba-banana complimentary food. Food and Nutrition Sciences, 4, 844-850.

[29] Uzeochina OB. (2007). Evaluation of the effect of processing techniques on the nutrients and anti-nutrients contents of pigeon pea (Cajanus cajan) seed flours. Journal of Food Science, 28, 76-77.

[30] Onwuka GI. (2005). Food analysis and instrumentation: Theory and practice Lagos: Naphtali Prints.

[31] Inyang UE and Ekpo VO. (2015). Physico-chemical properties and anti-nutrient contents of unripe banana and African yam bean flour blends. International Journal of Food Sciences and Nutrition, 4, 549-554.

[32] Eneobong HN. (2001). Eating right (A nutrition guide). Nigeria: Zoometer print Communications Ltd.

[33] Okpala LC and Okoli EC. (2011). Nutritional evaluation of cookies produced from pigeon pea, cocoyam and sorghum flour blends. African Journal of Biotechnology, 10, 433-438.

[34] Ekop AS, Obot IB and Ikpatt EN. (2008). Anti-nutritional factors and potassium bromate content in bread and flour samples in Uyo metropolis, Nigeria. European Journal of Chemistry, 5, 736-741.

\section{How to cite this article}

Adejumo PO, Adejumo AO, Edebiri O and Olukoya FO. (2020). Effect of unripe banana and pigeon pea flour on the chemical, anti-nutritional and sensory properties of whole wheat- based cookies. GSC Advanced Research and Reviews, $4(1), 17-23$. 